\title{
Variation in gametophytic and sporophytic features among three disjunct populations of Funaria hygrometrica
}

\author{
Shewli Bhattacharya1, S. N. Ojha² and Samit Ray ${ }^{1 凶}$ \\ 'Department of Botany, Visva-Bharati, Santiniketan - 731235, West Bengal \\ 2Integrated Science Education And Research Centre, Visva-Bharati, Santiniketan - 731235 \\ 凶Corresponding Author: ray_samit@rediffmail.com
}

\section{फ्यूनेरिया हाइग्रोमेट्रिका की तीन असंबद्ध जीवसंख्याओं में युग्मकोद्भिद एवं बिजाणुद्भिद रूपान्तरण}

\author{
शिवली भट्टाचार्य, एस. एन. ओझा एवं समीत रे
}

\section{सारांश}

प्रस्तुत शोध पत्र में भारत के शिलांग, श्रीनगर एवं दार्जिलिंग से संग्रहीत प्यूनेरिया हाइग्रोमेट्रिका की तीन जीवसंख्याओं के गेमेटोफाइटिक और स्पोरोफाइटिक वैशिष्ट्यों के रूपान्तरण का अध्ययन किया गया है। आकारिकी, वर्गिकी, बीजाणुओं के आयामिक तथा अलंकरण के विभिन्न मापदंडों का अध्ययन इस जाति के फ्यूनेरिया वंश में नियोजन के लिये महत्वपूर्ण हैं। एनोवा परीक्षण जाति की तीनों जीवसंख्याओं में तने की लंबाई, पत्तियों की लंबाई, चौड़ाई, आधारीय और शीर्षस्थ कोशिका आकार, सीटा की लम्बाई, कैफ्सूल की लंबाई, एक्जोस्टोम तथा एंडोस्टोम लंबाई, ध्रुवीय अक्ष एवं बीजाणुओं के विषुवतीय व्यास के पार्थक्य पर महत्वपूर्ण भिन्नतायें प्रदर्शित करता है। सामासिक आँकड़ों का पी.सी.ए ग्राफ तीनों सथानों के नमूनों में सन्निहित स्पष्ट पृथककरण को प्रदर्शित करता है। जलवायु-संबंधी कारकों और आकारिकी मापदण्डों के पारस्परिक सह-सम्बन्धों पर प्रामाणिक सादृश्य विश्लेषण निष्पादित किया गया है। प्रस्तुत अध्ययन यह स्थापित करता है कि प्रजातिय अभिनिर्धारण के लिए ज्यामितीय आकारिकी अभिमुखताओं के परिगणन न करके बीजाणु अलंकरण के साथ अन्य आकृति-मूलक वैशिष्ट्यों पर विचार किया जाना चाहिये ।

\section{ABSTRACT}

The paper reveals the variation of gametophytic and sporophytic in three different populations of Funaria hygrometrica collected from Shillong, Srinagar and Darjeeling. The morphology, dimensional parameters and ornamentation of spores are significant in delimitating the taxa in Funaria. ANOVA test showed significant differences in the length of stem length, leaf length \& breath, basal and apical cell size, length of seta, length of capsule, exostome and endostome length, polar axis and equatorial diameter of spores. The PCA graph of composite data shows clear segregation among three samples from three locations. Canonical Correspondence Analysis revealed the correlation between climatic factors and morphometric parameters. This study establishes that dimensional aspects should not be considered always for species identification and spore ornamentation should be considered along with other morphological features for species identification.

Keywords: Funaria, Moss, Spore-Ornamentation, Taxonomy, Variation. 


\section{INTRODUCTION}

The Genus Funaria Hedw. belongs to the subclass Funariidae, order Funariales, family Funariaceae (Goffinet \& al., 2009) and is distributed commonly from tropical to temperate zones of the world. Robinson (1968) described eight species under Funaria based on morphological characters viz. length of plant, shape of leaves, nature of costa, nature of margin, shape of capsule, symmetric / asymmetric nature of capsule, shape of operculum and nature of peristome. Among all the species found in India Funaria hygrometrica is one of the commonest species; collected from Western Himalaya (Kashmir to Nepal with foothills), South India (Western Ghats, Palni, Nilgiri), Jalpaiguri-Dooars, Chotonagpur and Orissa in India (Gangulee, 1974-1977). Due to this disjunctive distribution of $F$. hygrometrica many morphological parameters both in gametophyte and sporophyte show significant variations. Similar kinds of variation which are considered as taxonomically significant have also been reported in other mosses like Pogonatum dentum, Calliergonella cuspidata (Bergamini \& Peintiger, 2002; Hassel \& al., 2005). These variations can be attributed to the response of environmental conditions and an important way for the organisms to deal with variable environments (Schlichting, 1986). In the present study, we studied morphological variations both in gametophyte and sporophyte features including spore dimension and ornamentation of three populations of F. hygrometrica, collected from three geographically distant locations and also tried to correlate the climatic parameters with taxonomically important morphological characters.

\section{MATERIALS AND METHODS}

Specimens of F. hygrometrica were collected from Darjeeling, Srinagar and Shillong and brought to the laboratory, processed and preserved in the herbarium of Department of Botany, Visva-Bharati.. Correct identity of the plants confirmed with available literature Gangulee (1971-1980) and studied under dissecting microscope (Hund, Wetzlar). Photographs of the plant and microphotographs of significant features were taken using camera and trinocular microscope (Leica DM 2500).

Gametophytic characters were studied with regard to length and breadth of the shoot, leaf, apical and basal laminal cells, capsule, equatorial and polar diameter of spores, length of seta, length of exostome and endostome. Each parameters for ten specimens of each population were studied and subjected to statistical analysis.
Acetolysis of spores from three populations of F. hygrometrica were done following the method of Erdtman (1960). Acetolysed spores were used for measurement of dimension (spore diameter, polar axis, equatorial axis) while non-acetolysed dry spores with Gold-Paladium coat were observed with Hitachi S530 SEM at an accelerated voltage of $15 \mathrm{KV}$ for high quality micromorphmetry.

The morphometric data of the nine gametophytic (including spore dimension) and five sporophytic morphological parameters were subjected to analysis of variance (One way - ANOVA). Canonical Correspondence Analysis (CCA) (Ter Braak, 1986) was performed to determine whether variance in the morphological dimensions could be explained by climatic variables in three locations from where the specimens were collected. CCA ordination was tested for significance with a Monte Carlo test (500 runs) through CANOCO software.

\section{RESULT}

\section{TAXOMOMIC TREATMENT}

Funaria hygrometrica Hedw., Sp. Musc. Frond. 172. 1801.

Green to yellow green plants, usually 7-11; $7-11 \mathrm{~mm}$ high; lower leaves sparse with poorly developed costa; upper leaves narrow forming a rosette, oblong lanceolate or oblong obovate, $2-4 \mathrm{~mm}$ long, margin entire up to apex, costa strong, percurrent; lamina cells more elongated at base $(94.5 \mu \mathrm{m}-120.4 \mu \mathrm{m} \times 15.9-26.0 \mu \mathrm{m})$ and small at apex $(37.4-58.2 \mu \mathrm{m} \times 17.3 \mu \mathrm{m}-25.7 \mu \mathrm{m})$; seta apical, erect, arcuate, $37 \mathrm{~mm}-67 \mathrm{~mm}$ long; capsule arcuate - pyriform in shape, yellowish brown in colour, $3-4$ $\mathrm{mm} \times 0.8-1.5 \mathrm{~mm}$, capsule mouth colour red; peristome teeth typically epicranoid, outer teeth brown, length $479.33 \mu \mathrm{m}-629.07 \mu \mathrm{m}$, inner teeth hyaline, $400.4 \mu \mathrm{m}$ - $480.7 \mu \mathrm{m}$, inner peristome teeth slightly shorter than outer peristome teeth.

Specimen examined: Population I - India, Meghalaya, Shillong, $25.5788^{\circ} \mathrm{N}, 91.8933^{\circ} \mathrm{E}, 1525 \mathrm{~m}, 06.11 .2015$, Samit Ray, SL 11; Population II - India, Jammu Kashmir, Srina-

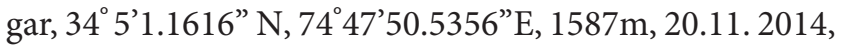
Rajat Sarkar, KM 21; Population III - India, West Bengal, Darjeeling, $27.0360^{\circ} \mathrm{N}, 88.2627^{\circ} \mathrm{E}, 2042 \mathrm{~m}, 18.9 .2016$, Samit Ray, WB 68.

Table 1 shows the phenotypic differences (other than dimensions) among three populations of F. hygrometrica (Fig. 1). Leaves in populations from Shillong 
are oblonglanceolate whereas leaves in other two populations are oblong obovate. Costa in populations from Darjeeling is shortly excurrent but it is percurrent in other two populations. Seta is two much long $(37 \sim 67 \mathrm{~mm})$ in populations from Srinagar. Seta of populations from Srinagar and Darjeeling are of medium length $(14 \sim 24 \mathrm{~mm})$. In populations from Srinagar, exostome and endostome are of same height. But in other two populations, endostome is slightly shorter than exostome. (Fig. 1)

Table 2 shows the wide range of differences among dimensional morphometric parameters of three populations. From this table it can be summarized that, spore size of $F$. hygrometrica from Darjeeling is largest among these three populations. Variations are noticed in range of polar axis and equatorial diameter among three populations of

Table -1. Range of phenotypic variations among populations of F. hygrometrica

\begin{tabular}{lllll}
\hline Locations & Shape of leaves & Costa & Seta length & Peristome teeth \\
\hline Shillong & Oblong lanceolate & Percurrent & Too much long $(37 \sim 63 \mathrm{~mm})$ & Endostome slightly shorter than exostome \\
Srinagar & Oblong obovate & Percurrent & Medium length $(14 \sim 20 \mathrm{~mm})$ & Length of exostome and endostome almost same \\
Darjeeling & Oblong obovate & $\begin{array}{l}\text { Shortly } \\
\text { excurrent }\end{array}$ & $\begin{array}{l}\text { Medium length } \\
(16 \sim 24 \mathrm{~mm})\end{array}$ & Endostome slightly shorter than exostome \\
\hline
\end{tabular}

Table -2. Range of values of morphometric parameters studied

\begin{tabular}{llll}
\hline Morphological parameter $(\mathbf{m m})$ & $\begin{array}{l}\text { F. hygrometrica } \\
\text { (Shillong) }\end{array}$ & $\begin{array}{l}\text { F. hygrometrica } \\
\text { (Srinagar) }\end{array}$ & $\begin{array}{l}\text { F. hygrometrica } \\
\text { from (Darjeeling) }\end{array}$ \\
\hline Stem length & $7.0-11.0$ & $3-3.5$ & $5-10$ \\
Leaf length & $2-4$ & $2.03-2.8$ & $2-4$ \\
Leaf breadth & $0.542-0.633$ & $0.31-0.45$ & $0.3-0.55$ \\
Upper leaf cell length & $0.037-0.056$ & $0.026-0.047$ & $0.027-0.48$ \\
Upper leaf cell breadth & $0.017-0.025$ & $0.008-0.009$ & $0.013-0.021$ \\
Lower leaf cell length & $0.09-0.12$ & $0.076-0.103$ & $0.094-0.138$ \\
Lower leaf cell breadth & $0.015-0.026$ & $0.01-0.014$ & $0.017-0.024$ \\
Seta length & $37.0-63.0$ & $12.0-23.0$ & $12.0-29.0$ \\
Capsule urn length & $3-4$ & $2-3$ & $3-3.5$ \\
Capsule urn breadth & $0.8-1.5$ & $0.8-1.2$ & $0.8-1.0$ \\
Peristome height & $0.47-0.62$ & $0.31-0.38$ & $0.50-0.59$ \\
Polar axis of spore & $0.008-0.010$ & $0.0105-0.0118$ & $0.012-0.015$ \\
Equatorial diameter of spore & $0.0107-0.0124$ & $0.0121-0.0148$ & $0.0138-0.0185$ \\
Ornamentation & Gemmate & Gemmate & Gemmate \\
\hline
\end{tabular}

F. hygrometrica. But in three populations of this species spore ornamentation is same.

The populations from three locations display highly significant differences in the morphometric parameters (stem length, leaf length, leaf breadth, upper leaf cell length and breadth, lower leaf cell length and breadth, seta length, capsule length, exostome and endostome height, length of polar axis and equatorial diameter of spore). The ANOVA result was found marginally insignificant for capsule breadth only. (Table 3)

The PCA graph (Fig. 3) of composite data (taking morphometric parameters of three populations in consideration) shows clear segregation among three samples from three locations. The proportional variances accounted for by PC1 and PC2 are 0.583 and 0.4
Table 3: ANOVA results

\begin{tabular}{ll}
\hline Morphological parameter $(\mathbf{m m})$ & Level of significance $(\mathbf{p})$ \\
\hline Stem length & $3.37 \mathrm{E}-08$ \\
Leaf length & $8.12 \mathrm{E}-05$ \\
Leaf breadth & $9.12 \mathrm{E}-06$ \\
Upper leaf cell length & 0.00201 \\
Upper leaf cell breadth & $2.5 \mathrm{E}-07$ \\
Lower leaf cell length & 0.0025 \\
Lower leaf cell breadth & $2.51 \mathrm{E}-06$ \\
Seta length & $7.39 \mathrm{E}-12$ \\
Capsule length & 0.000243 \\
Capsule breadth & 0.064 (marginally \\
& insignificant) \\
Exostome height & $2.53 \mathrm{E}-12$ \\
Endostome height & $3.65 \mathrm{E}-12$ \\
Polar axis of spore & $1.48 \mathrm{E}-08$ \\
Equatorial diameter of spore & $7.35 \mathrm{E}-08$ \\
\hline
\end{tabular}



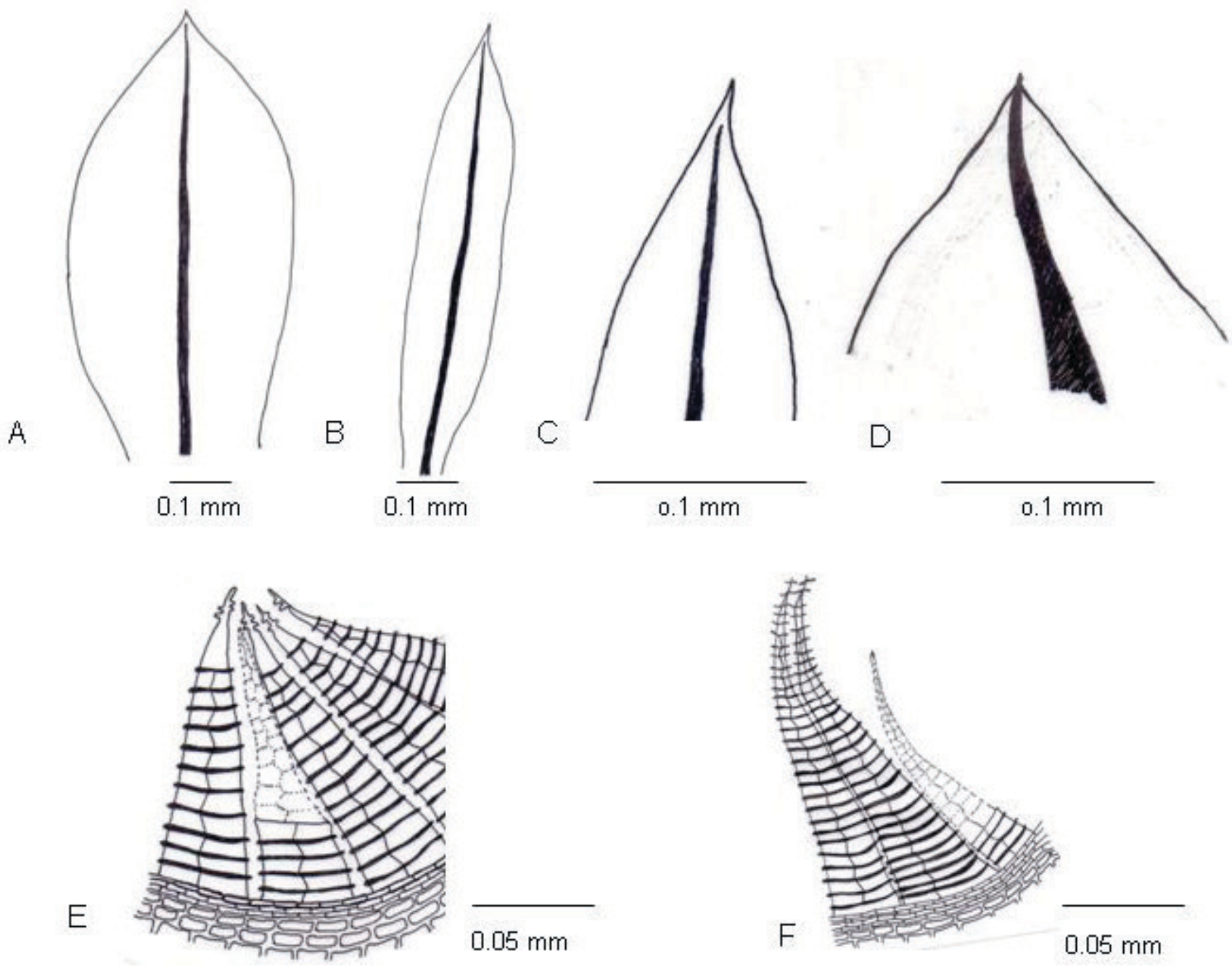

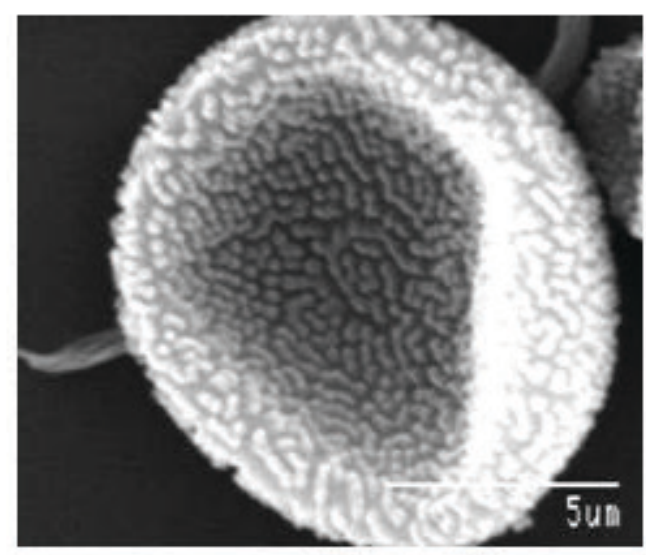

G

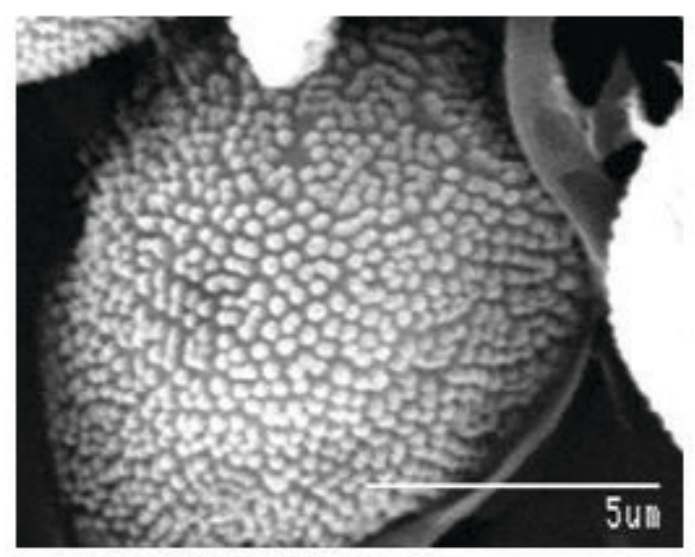

$\mathrm{H}$

Fig. 1: Funaria hygrometrica Hedw A, B. Variation in leaf shape; C, D. Variation in costa; E, F. Variation in length of endostome; G. Apertural area in the proximal end of spore with gemmate ornamentation; H. Distal end of spore with gemmate ornamentation. 


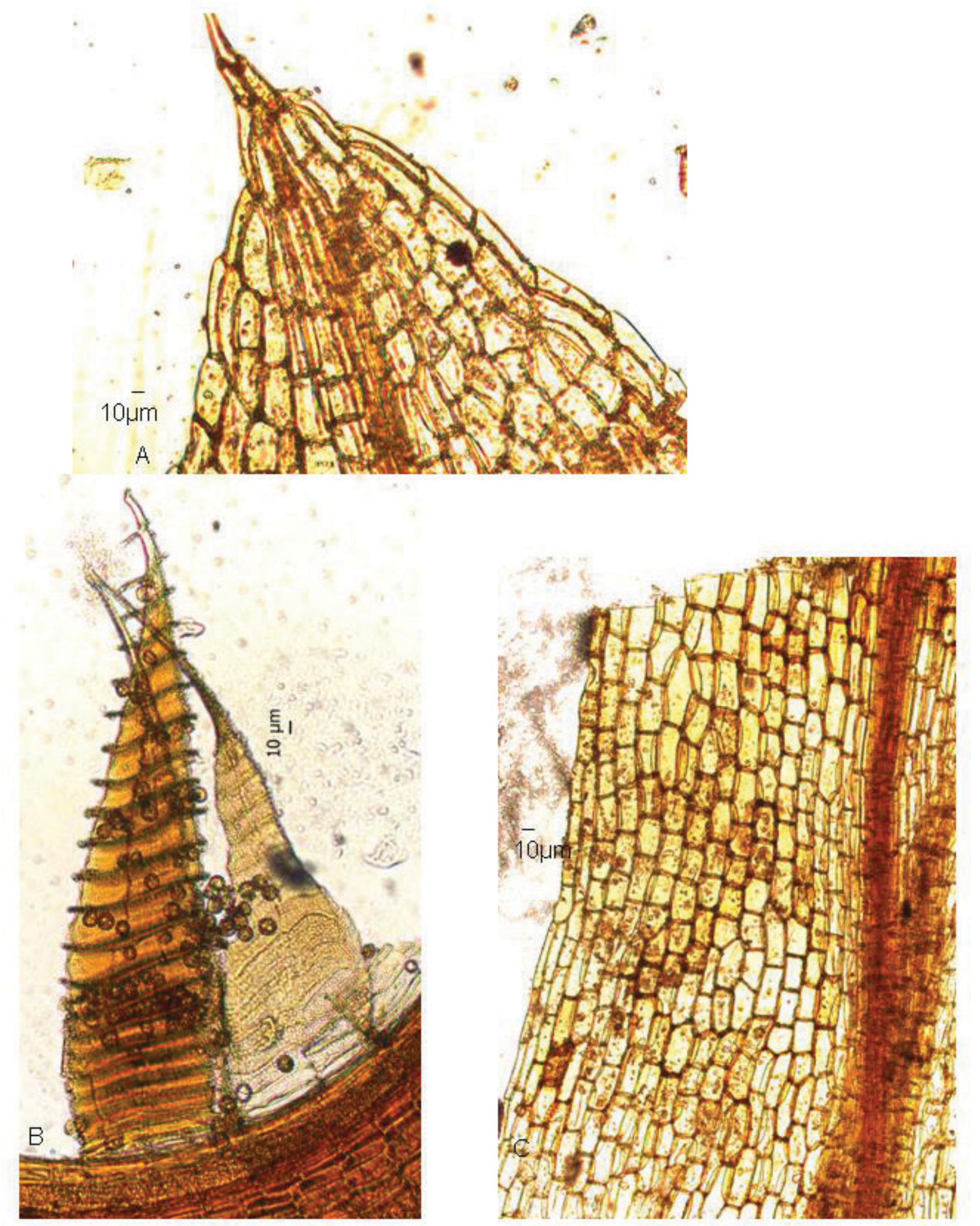

Fig. 2: Funaria hygrometrica Hedw Microphotographs of A: shortly excurrent costa with upper laminar cells B: exostome and endostome C: Lower lamina cells with well developed costa 
respectively. The component loadings for samples from Shillong are highest (0.812) foe PC 1 . However, for samples from Darjeeling and Kashmir, it is highest (0.692 and 0.721 respectively) for PC2. Hence this PCA result shows that the morphometric variations of populations from Shillong are significant from those collected from Kashmir and Darjeeling. At the same time the population from Kashmir and Darjeeling are mutually different with statistical significance.

Table 4 shows the environmental data of three locations. Among these three, elevation of Darjeeling is highest. In Shillong, there is heavy rainfall in both summer and monsoon but low rainfall in summer and monsoon in Kashmir.

According to CCA graph (Fig. 4) leaf size and lamina cell size; capsule size and peristome height are equally influenced by elevation and rainfall during winter. Winter rainfall also influences spore size. Length of gametophore is equally dependent upon elevation and temperature in winter.

\section{DISCUSSION}

F. hygrometrica is distributed all over the Himalayas Darjeeling, Arunachal Pradesh, Manipur, Nagaland, Meghalaya, Jammu and Kashmir and also in the plains like - Jalpaiguri dooars, Chotonagpur, Orissa (Gangulee, 1974-77). Western and eastern Himalayas are considered as center of origin and diversification of bryophytes and the diversified species might have spread in different phytogeographical regions. In the present study, three populations of $F$. hygrometrica have been collected from Shillong, Srinagar and Darjeeling - three geographically distant locations.

Variations in morphological features as well as in morphometric values of different features are not only evident from the present study but also from earlier literature. While Gangulee (1974-77) mentioned range of leaf length and leaf breadth as $2.5-4 \mathrm{~mm}$ and $0.9-1.4 \mathrm{~mm}$ respectively, the populations collected from Srinagar shows leaf length $<2.5 \mathrm{~mm}$ and range of leaf breadth 0.5-0.8 mm. (Table 2). Khoshravesh and Osaloo (2007) reported the spore size of F. hygrometrica as $16.90 \times 17.36 \mu \mathrm{m}$. Spores of this species collected from populations of Shillong and Srinagar are smaller in size $(8-11 \times 10-14 \mu \mathrm{m})$ (Table 2). Spore size has a relation with altitude of the place from where the population is collected. Spore size is larger (up to $25 \mu \mathrm{m}$ ) in populations from higher altitude (Robinson, 1968). In the present study, spores of populations from Darjeeling are largest $(13.8-18.5 \mu \mathrm{m})$ as the altitude of Darjeeling is highest among the three locations. All of these three populations show gemmate ornamentation pattern (a sexine element that is constricted at its base, higher than $1 \mu \mathrm{m}$ and approximately the same width as its height (Iversen \& Troels-Smith, 1950) of the spore wall. Though various types of spore wall ornamentations were reported for the family Funariaceae (McIntosh, 2007) gemmate ornamentation has been reported for F. hygrometrica (Khoshravesh $\&$ Osaloo, 2007). Hence, conservative nature of spore wall ornamentation at species level as revealed under SEM observations is established. This view has been supported by previous works (Luzi-Ponzo \& Barth, 1998, 1999; Savaroğlu \& al., 2007; Savaroğlu \& Potoğlu Erkarai, 2008).

Shaw (1993) tried to determine through statistical methods, whether there is subtle morphological differences among populations and whether there are regional patterns of morphological variability that can only be ascertained by an intensive morphometric analysis. In the present study, ANOVA was used to show whether the differences in thirteen phenotypic characters (important for taxonomic identification of species) of three populations of F. hygrometrica, collected from three different phytogeographical regions of India (Table 2) are significant. The significant variations amongst these three populations may be due to variations in climatic factors as indicated in Table 4 and the property of phenotypic plasticity. In a later study, Hassel $\&$ al. (2005) have shown that phenotypic plasticity enables

Table 4: Environmental data of three locations

\begin{tabular}{lcccccc}
\hline Location & $\begin{array}{c}\text { Elevation } \\
(\mathrm{m})\end{array}$ & $\begin{array}{c}\text { Temp. at } \\
\text { Summer } \\
\left({ }^{\circ} \mathrm{C}\right)\end{array}$ & $\begin{array}{c}\text { Temp. at winter } \\
\left({ }^{\circ} \mathrm{C}\right)\end{array}$ & $\begin{array}{c}\text { Rainfall at } \\
\text { summer } \\
(\mathrm{mm})\end{array}$ & $\begin{array}{c}\text { Rainfall at } \\
\text { monsoon } \\
(\mathrm{mm})\end{array}$ & $\begin{array}{c}\text { Rainfall at } \\
\text { Winter } \\
(\mathrm{mm})\end{array}$ \\
\hline Shillong & 1525 & 23 & 4 & 231.4 & 379.8 & 16.7 \\
Kashmir & 1587 & 24.1 & 2.5 & 85 & 55.8 & 45.16 \\
Darjeeling & 2042 & 13.7 & 7.6 & 117.7 & 589.06 \\
\hline
\end{tabular}




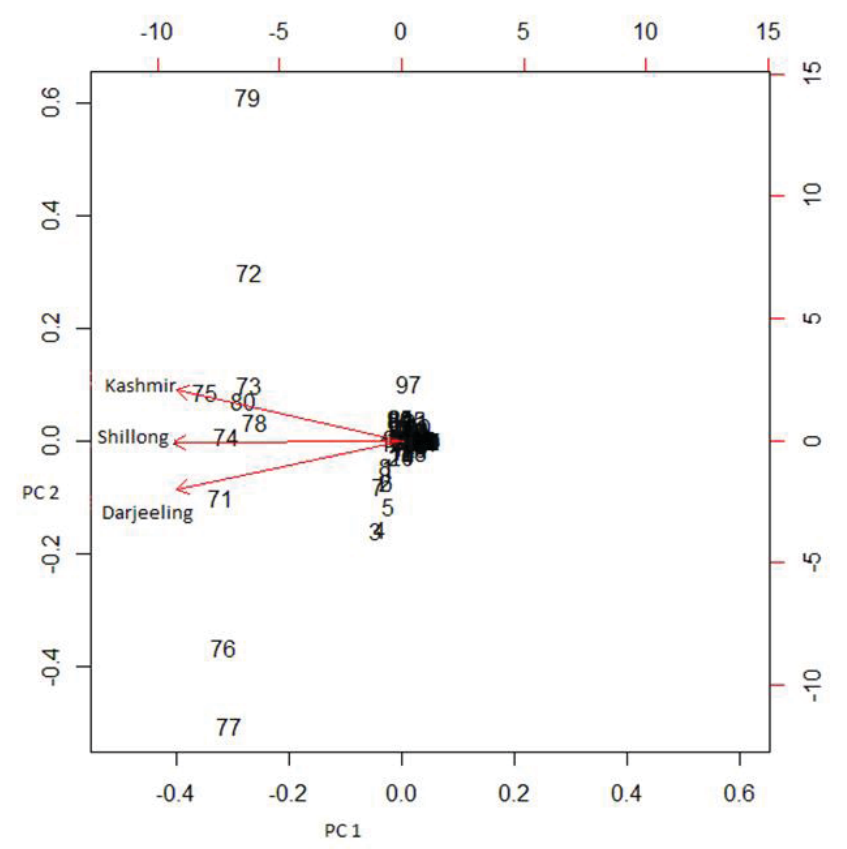

Fig. 3: PCA graph of composite morphometric data.

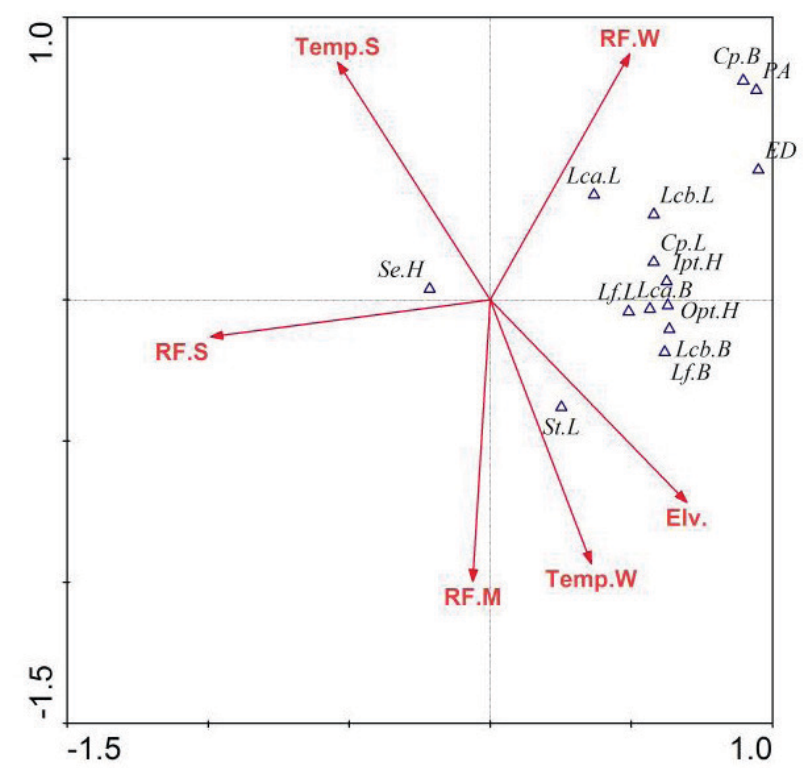

Fig. 4: CCA graph showing correlation between morphometric data of three populations and climatic variables of three locations.

individuals to alter traits in response to environmental condition. CCA analysis performed by Song \& al. (2015) showed that altitude, vegetation coverage and temperature were the key factors influencing the distribution of a moss Didymodon. In this work, Fig. 3 shows elevation and winter rain fall is the most influencing factors regarding the variations found in leaf, capsule, peristome teeth and spore size of three different populations. Hence we support the view of Price \& al. (2003) that, environment is an inducing factor for phenotypic plasticity.

From our study we come to the following conclusions - firstly, though dimensions of some gametophytic and sporophytic structures were used as key for identification of species of moss, dimensions may vary significantly due to change in climatic and environmental factors. So dimensions of different parts of gametophore and sporophyte should be excluded especially in case of complex or highly morphologically variable species from the keys of species delimitation. Secondly, spore ornamentation pattern is found to be a conserved character at least at the species level. So apart from description of plant parts, spore ornamentation must be considered along with other phenotypic characters as identification parameter for species.

\section{REFERENCES}

BERGAMI, A. AND M. PEINTINGER 2002. Effects of light and nitrogen on morphological plasticity of the moss Calliergonella cuspidata. Oikos 96: 355-363.

ERDTMAN, G. 1960. The acetolysis method. Svensk Bot. Tidskr. 54: 561-564.

HASSEL, K., B. PEDERSEN AND L. SÖDERSTRÖM 2005. Changes in life-history traits in an expanding moss species : phenotypic plasticity or genetic differentiation ? A reciprocal transplantation experiment with Poganatum dentatum. Ecography 28: 71 - 80.

GANGULEE H.C. 1974 - 77. Mosses of Eastern India and adjacent regions, Vol. II (Fasc. 4 - 6) Books and Allied Limited, Kolkata, India.

GOFFINET, B., W. R. BUCK AND J. SHAW 2009. Morphology, anatomy and classification of the Bryophyta. In: Goffinet B, Shaw J (Eds) Bryophyte Biology. Cambridge University Press, UK, 55-138.

IVERSEN, J. AND J. TROELS-SMITH 1950. Pollenmorfologiske definitioner og typer. Danmarks geologiske under søgeolse 4, No. 8.

KHOSHRAVESH, R. AND S. H. OSALOO 2007. Spore morphology of certain mosses of northern Iran: Taxonomical and ecological implications. Iran. J. Bot. 13 (2): 150 - 159.

LUI-PONZO A. P. AND O. M. BORTH 1998. Spore morphology of some Bruchiaceae species (Bryophyta) from Brazil. Grana 37 (4): 222 - 227.

LUI-PONZO, A. P. AND O. M. BARTH 1999. Spore morphology of some Dicranaceae species (Bryophyta) from Brazil. Grana 38:42-49. 
MCINTOSH, T. T. 2007. Funariaceae schwägrischen. Flora of North America (27): 180 - 189.

PRICE, T.D., A. QVARNSTRÖM, AND D.E. IRWIN 2003. The role of phenotypic plasticity in driving genetic evolution. Proc. R. Soc. Lond. B. 270, 1433-1440.

ROBINSON, H. 1968. Notes on Bryophytes from the Himalayas and Assam. Bryologist 71(2): 82-97.

SAVAROĞLU, F., I. P. ERKARA, C. BAYCU AND M. ALKAN 2007. Spore morphology of some Bryaceae Schwigr. species (Bryophyta) from Turkey. Int. J. Nat. Eng. Sci. 1 (2): 49 - 54. SAVAROĞLU, F AND I.P. ERKARA 2008. Observation of spore morphology of some Pottiaceae Schimp. species (Bryophyta) in Turkey. Pl. Syst. Evol. 271: 93 - 99.
SCHLICHTING, C.D. 1986. The evolution of phenotypic plasticity in plants. Annu. Rev. Ecol. Syst. 17: 667-693.

SHAW, A.J. 1993. Morphological uniformity among widely disjunct populations of the rare "Copper moss" Scopelophila cataractae (Pottiaceae). Syst. Bot. 18(3): 525-537.

SONG, S., X. LIU, X. BAI, X. ZHANG, C. YU AND X. SHAO 2015. Impacts of environmental heterogeneity on moss diversity and distribution of Didymodon (Pottiaceae) in Tibet, China. Plos one. 1-17.

TER BRAAK, C. J. F. 1986. Canonical correspondence analysis: A new eigen vector technique for multivariate direct gradient analysis. Ecology 67: 1167-1179. 